\title{
Bacterial Lipopolysaccharide Primes Human Neutrophils for Enhanced Release of Arachidonic Acid and Causes Phosphorylation of an 85-kD Cytosolic Phospholipase $A_{2}$
}

\author{
Martin E. Doerfler, Jerrold Weiss, James D. Clark, ${ }^{\star}$ and Peter Elsbach \\ Departments of Medicine and Microbiology, New York University School of Medicine, New York 10016; and *Genetics Institute Inc., \\ Cambridge, Massachusetts 02146
}

\begin{abstract}
Production of leukotriene $\mathrm{B}_{4}\left(\mathrm{LTB}_{4}\right)$ by human neutrophils (PMN) in response to different stimuli is increased after pretreatment with lipopolysaccharides (LPS). We have analyzed the steps in arachidonic acid (AA) metabolism affected by LPS by examining release of $A A$ and its metabolites from $\left[{ }^{3} \mathbf{H}\right] \mathrm{AA}$ prelabeled PMN. Pretreatment of PMN for 60 min with up to 1 $\mu \mathrm{g} / \mathrm{ml}$ of LPS alone had no effect, but release of $\left[{ }^{3} \mathrm{H}\right] \mathrm{AA}$ was stimulated up to fivefold during subsequent stimulation with a second agent. In the absence of LPS-binding protein (LBP), priming was maximal after pretreatment of PMN with $10 \mathrm{ng}$ of LPS $/ \mathrm{ml}$ for $60 \mathrm{~min}$; in the presence of LBP maximal priming occurred within $45 \mathrm{~min}$ at $0.1 \mathrm{ng}$ of LPS/ml and within $15 \mathrm{~min}$ at $100 \mathrm{ng}$ of LPS/ml. Treatment of PMN with $10 \mathrm{ng}$ of LPS/ $\mathrm{ml}$ also increased uptake of opsonized zymosan by up to $60 \%$. Phospholipids are the source of released $\left[{ }^{3} \mathrm{H}\right] \mathrm{AA}$. No release was observed from $\left[{ }^{14} \mathrm{C}\right]$ oleic acid (OA)-labeled PMN suggesting that phospholipolysis may be specific for $\left[{ }^{3} \mathbf{H}\right] \mathbf{A A}$ labeled phospholipid pools. Cytosol from PMN primed with LPS contains two to three times the phospholipase $A_{2}\left(P L A_{2}\right)$ activity of control PMN, against 1-palmitoyl- $\left[2-{ }^{14} \mathrm{C}\right]-$ arachidonoyl-phosphatidylcholine. This activity is $\mathrm{Ca}^{2+}$ dependent and dithiothreitol resistant. LPS priming is accompanied by reduced migration during SDS-PAGE of an 85-kD protein, identified as a cytosolic PLA $\mathrm{A}_{2}$. The extent and kinetics of this effect of LPS on CPLA $A_{2}$ parallel the priming of $\left[{ }^{3} \mathrm{H}\right] \mathrm{AA}$ release, both depending on LPS concentration either with or without LBP. These findings suggest that priming by LPS of AA metabolism by PMN includes phosphorylation of an AA-phospholipid-selective cytosolic PLA $\mathbf{A}_{2}$ that is dissociated from activation until a second stimulus is applied. (J. Clin. Invest. 1994. 93:1583-1591.) Key words: CD14 $\bullet$ leukotriene $B_{4} \cdot$ lipopolysaccharide-binding protein $\bullet$ mitogen-activated protein kinase
\end{abstract}

\section{Introduction}

Infections with Gram-negative organisms and septic shock remain a major cause of morbidity and mortality of hospitalized patients (1). Outer membrane LPS plays a central role in alerting the host to the presence of Gram-negative bacteria. The

Address correspondence to Dr. Martin E. Doerfler, Division of Pulmonary/Critical Care Medicine, New York University School of Medicine, 550 First Avenue, New York, NY 10016.

Received for publication 2 July 1993 and in revised form 14 October 1993.

J. Clin. Invest.

(c) The American Society for Clinical Investigation, Inc. 0021-9738/94/04/1583/09 \$2.00

Volume 93, April 1994, 1583-1591 host responses can be beneficial, by optimizing defensive reactions, or may become excessive and self-destructive as in septic shock. In monocytes, macrophages, and PMN a variety of cell responses to LPS are mediated by CD14, a glycosyl-phosphatidylinositol-linked membrane protein. These responses are, in turn greatly amplified by first complexing of LPS to an extracellular LPS-binding protein (LBP) ${ }^{1}$ of hepatic origin $(2,3)$.

The PMN is a major target for the action of bacterial LPS and plays an essential role in host defense to bacterial infection. LPS in concentrations as low as $0.1 \mathrm{ng} / \mathrm{ml}$ has been shown to "prime" PMN for enhanced production of leukotriene $B_{4}$ $\left(\mathrm{LTB}_{4}\right)$ in response to both particulate (opsonized zymosan; $\mathrm{OZ}$ ) and soluble (A23187, PMA) stimuli (4). $\mathrm{LTB}_{4}$ is a potent chemo-attractant (5) and promotes fluid extravasation into the interstitium by PMN-mediated increases in vascular permeability (6). The initial step in eicosanoid production is the release of arachidonic acid from the $s n-2$ position of phospholipase (PL). The enzyme(s) involved in hydrolysis have not yet been definitively identified. An $85-\mathrm{kD}$ cytosolic phospholipase $\mathrm{A}_{2}$ $\left(\mathrm{CPLA}_{2}\right)$ with preference for AA containing PL has been described in rabbit PMN and HL-60 cells $(7,8)$ and similar enzymes have been purified from macrophage-like cell lines (911). Several granule-associated $\mathrm{PLA}_{2}$ have also been characterized which have an uncertain role in AA metabolism $(12,13)$. PLC followed by diacylglycerol-lipase with or without monoacylglycerol-lipase digestion of PL is probably of limited significance in AA metabolism by PMN (14). $\mathrm{LTB}_{4}$ produced by 5-lipoxygenase ( $5 \mathrm{LO}$ ) is the major PMN metabolite of released AA. Upregulation by LPS of either a lipolytic step and/or $5 \mathrm{LO}$ activity could account for the enhanced $\mathrm{LTB}_{4}$ production found after a second stimulus.

LPS triggers increased surface expression of CR1 and CR3 $(15,16)$ and enhanced phagocytosis of opsonized bacteria (17) and yeast (18). Thus, increased phagocytic activity might also contribute to increased $\mathrm{AA}$ metabolism ( $\mathrm{LTB}_{4}$ production) triggered by a particulate stimulus.

In this report we show that priming of PMN by LPS results in preferential hydrolysis of AA containing phospholipids when a second stimulus is applied. LPS priming is both amplified and accelerated by the presence of LBP. LPS also increases phagocytosis of OZ by PMN, which might contribute to improved host defense, but does not account for the increase in AA release. Priming of PMN is accompanied by phosphorylation of an arachidonoyl-selective $85-\mathrm{kD} \mathrm{cPLA}_{2}$ and greater DTT-resistant, $\mathrm{Ca}^{2+}$-dependent, arachidonoyl-selective $\mathrm{PLA}_{2}$

1. Abbreviations used in this paper: $\mathrm{CE}$, cholesterol ester, cPLA, cytosolic phospholipase $\mathrm{A}_{2}$; LBP, LPS-binding protein; LT, leukotriene; MG, monoglyceride; OZ, opsonized zymosan; PE, phosphatidyl ethanol-amine; PI, phosphatidylinositol; PKC, phosphokinase C; PL, phospholipase; PS, phosphatidyl serine; TG, triglyceride. 
activity in cytosolic fractions, suggesting that phosphorylation of this $\mathrm{cPLA}_{2}$ may contribute to the enhanced release of AA and production of $\mathrm{LTB}_{4}$ by primed PMN.

\section{Methods}

Materials. Special reagents used are as follows: sterile pyrogen- and, preservative-free heparin (porcine intestine), (Squibb-Marsam, Cherry Hill, NJ), Pyrogen-free dextran, mol wt range 200,000300,000 (United States Biochemical Corp., Cleveland, OH), HBSS (GIBCO, Grand Island, NY), [ $\left.{ }^{3} \mathrm{H}\right] \mathrm{AA}$ 60-100 Ci/mmol, L- $\alpha-1-$ palmitoyl- $\left[2-{ }^{14} \mathrm{C}\right]$ arachidonoyl-phosphatidylcholine $40-60 \mathrm{mCi} / \mathrm{mmol}$, $\left[{ }^{14} \mathrm{C}\right.$ ] oleic acid (OA) $40-60 \mathrm{mCi} / \mathrm{mmol}$ (Dupont-New England $\mathrm{Nu}-$ clear, Boston, MA), Ficoll-Hypaque, (lymphocyte separation media; Organon Teknika Corp., Durham, NC), HSA (Armour Pharmaceutical Co., Kanakee, IL), LPS from Salmonella minnesota (Re595) (List Biological Laboratories, Campbell, CA), zymosan, FITC, FMLP, ionophore A23187, PMA, $\alpha$-phorbol-diacetate, PGB $_{2}$, L- $\alpha$-1-palmitoyl-2arachidonoyl-phosphatidylcholine, phosphatidylethanolamine, phosphatidylinositol, phosphatidylserine, aprotonin, chymostatin, pepstatin, PMSF, $N$-tosyl-L-phenylalanine chloromethyl ketone (TPCK), iodoacetamide and fatty acid-free BSA (Sigma Chemical Co., St. Louis, MO), HPLC grade ethanol (Aldrich Chemical Co., Milwaukee, WI), HPLC water (J. T. Baker Inc., Phillipsburg, NJ), methyl-formate redistilled (19) (Eastman-Kodak Co., Rochester, NY), HPLC grade methanol and acetonitrile (Burdick-Jackson, Muskegon, MI), $\mathrm{LTB}_{\mathbf{4}}$, $\mathrm{LTB}_{4}-\mathrm{OH}$, and $\mathrm{LTB}_{4}-\mathrm{COOH}$ standards (BIOMOL Research Laboratories, Plymouth Meeting, PA), anti-CD14 mAb (MY4) and isotype control $\mathrm{mAb}\left(\mathrm{IgG}_{2 \mathrm{~B}}\right)$ (Coulter Corp., Hialeah, FL), protein-A-sepharose (Pharmacia, Uppsala Sweden), alkaline phosphatase (Boerhinger Manheim Biochemicals, Indianapolis, IN). mAb 1,1,1 against cPLA and rabbit polyclonal antiserum against ${ } P L A_{2}$ were obtained as previously described (20). LBP was provided by Drs. Peter Tobias and Richard Ulevitch (Scripps Institute, LaJolla, CA).

Laboratory glassware and sonicator micro-tips were baked in dry heat for $4 \mathrm{~h}$ at $180^{\circ} \mathrm{C}$ to eliminate contaminating LPS. All reagents and buffers were determined to be LPS free by a chromogenic limulus lysate assay (Whittaker M.A. Bioproducts, Walkersville, MD) sensitive to $10 \mathrm{pg} / \mathrm{ml}$ of United States standard endotoxin.

Preparation of neutrophils. Neutrophils were isolated from heparinized venous blood of normal volunteers by standard techniques as previously described $(4,21)$. The blood was mixed with $3 \%$ dextran at a 1:2 ratio and allowed to stand for $20 \mathrm{~min}$ followed by Ficoll-Hypaque centrifugation at $250 \mathrm{~g}$ (model IEC Centra 7R; International Equipment Co., Needham Hts., MA) for $30 \mathrm{~min}$ at $18^{\circ} \mathrm{C}$. The cell pellet was subjected to hypotonic lysis to remove contaminating red cells then hypertonic saline to achieve isotonicity and was resuspended in HBSS $(-)$ at the desired concentration. The final suspensions consisted of $>98 \%$ neutrophils, $>98 \%$ of which excluded trypan blue. Platelet contamination was $<0.5 \%$.

Labeling of PMN with $\left[{ }^{3} \mathrm{H}\right] A A$ or $\left[{ }^{14} \mathrm{C}\right] \mathrm{OA}$. $\left[{ }^{3} \mathrm{H}\right] \mathrm{AA}$ or $\left[{ }^{14} \mathrm{C}\right] \mathrm{OA}, 4$ $\times 10^{4} \mathrm{cpm} / 10^{6} \mathrm{PMN}$ in ethanol were dried under $\mathrm{N}_{2}$. PMN were added and incubated in a shaking bath at $37^{\circ} \mathrm{C}$ for $30 \mathrm{~min}$. The cells were then washed three times with $\mathrm{HBSS}(-)$ containing $1.5 \%$ HSA and incubated for an additional $10 \mathrm{~min}$ to chase unincorporated labeled-FFA into ester positions. HSA was added to a final concentration of $1.5 \%$.

Preparation of endotoxin. Highly purified protein-free LPS extracted from $S$. minnesota $\operatorname{Re} 595$ mutant was prepared as a stock solution $(1 \mathrm{mg} / \mathrm{ml})$ in sterile, pyrogen-free water and sonicated as previously described (4).

Neutrophil priming by LPS. $250 \mu$ of a neutrophil suspension (2.0 $\left.\times 10^{7} / \mathrm{ml}\right)$ in HBSS $(-)$ with or without LPS was incubated in a shaking water bath at $37^{\circ} \mathrm{C}$ for $45-60 \mathrm{~min}$ in most experiments or for varied times as indicated $(4,21)$. After the priming incubation $>95 \%$ of the neutrophils excluded trypan blue.

Preparation of stimulants. A stock solution of $\mathrm{OZ}$ was prepared by incubating zymosan with fresh human serum at $37^{\circ} \mathrm{C}$ for $20 \mathrm{~min}$ and resuspending in $0.9 \% \mathrm{NaCl}$ at $50 \mathrm{mg} / \mathrm{ml}$ after four washes. FITC-labeled $\mathrm{OZ}$ was prepared by incubating zymosan in FITC $(1 \mathrm{mg} / \mathrm{ml})$ in $0.05 \mathrm{M}$ sodium carbonate buffer for $10 \mathrm{~min}$ at $20^{\circ} \mathrm{C}$ and washing three times before opsonization. Stock solutions of calcium ionophore A23187 were stored in ethanol, PMA, and $\alpha$-phorbol diacetate in DMSO and FMLP in PBS at $-70^{\circ} \mathrm{C}$. The stimulants were diluted in HBSS (-) on the day of use with the maximal final concentration of ethanol or DMSO not exceeding $0.05 \%$.

Stimulation of primed cells for $\mathrm{LTB}_{4}$ generation. After incubation of the cell suspension with LPS, calcium and magnesium salts were added to a final concentration equivalent to that present in $\operatorname{HBSS}(+)$. The stimulant was then added, and the cell suspension incubated for the desired time. Incubations were terminated with the addition of 1.5 vol of iced HPLC grade ethanol containing $\mathrm{PGB}_{2}(200 \mathrm{ng})$ as an internal standard and then refrigerated at $-20^{\circ} \mathrm{C} . \mathrm{LTB}_{4}$ and metabolites were extracted using the method of Shak (19) and quantitated by HPLC as previously described $(4,19)$. A Waters chromatography system (Millipore Corp., Milford, MA) was used with dual pumps (model 510), an autosampler (WISP model 712), a variable wavelength UV detector (model 481 ) at $270 \mathrm{~nm}$, an Ultrasphere $\mathrm{C} 18$ column $(4.7 \mathrm{~mm}$ $\times 250 \mathrm{~mm}$; Beckman Instruments, Inc., Palo Alto, CA) with 5- $\mu \mathrm{m}$ particles, and a $(4.7 \times 45 \mathrm{~mm})$ precartridge. Chromatogram plots and integrations for peak areas were generated using a Waters model 746 Data module. Concentrations of $\mathrm{LTB}_{4}$ and metabolites were obtained from the integrated areas by comparison to standards run under identical conditions. The limit of detection of the assay is $1.0 \mathrm{ng}$ of $\mathrm{LTB}_{\mathbf{4}}$.

Determination of the release of $\left[{ }^{3} \mathrm{H}\right] \mathrm{AA}$ or $\left[{ }^{14} \mathrm{C}\right] \mathrm{OA}$. After incubation the cells were either sedimented by centrifugation at $25,000 \mathrm{~g}$ for 2 min and a portion of the supernatant removed for counting in a liquid scintillation counter (Beckman LS500TD) or the whole-cell suspension was extracted and the FFA were separated from other lipid species by column chromatography as described below. The identical results were obtained by the two methods and therefore experiments were routinely analyzed by the first method. 2-3\% of total radiolabeled FFA remained in the supernatant following the labeling procedure described above and an additional $0.5-1.0 \%$ radiolabeled FFA accumulated in the supernatant during subsequent incubations of unprimed, unstimulated PMN in the presence of $1.5 \%$ HSA. The percentage of radiolabeled FFA released from esterified lipids, in response to LPS and or subsequent stimulation, was determined as [cpm (supernatant $x$ ) - cpm (supernatant of unstimulated cells)/(cpm (total) - cpm (supernatant of unstimulated cells)) $] \times 100$.

Determination of the $\left[{ }^{3} \mathrm{H}\right] \mathrm{AA}$ or $\left[{ }^{14} \mathrm{C}\right] \mathrm{OA}$ content of PMN phospholipids. Total lipids in the PMN suspensions were extracted according to the method of Bligh and Dyer (22). Lipid classes were separated using the solid-phase method of Kaluzny et al. (23) and Bond Elut aminopropyl cartridges (Analytichem International, Harbor City, CA). The extract was fractionated into FFA, phospholipid, cholesterol ester (CE), triglyceride ( TG), diglyceride (DG), and monoglygeride (MG) and each fraction was counted. The $\mathrm{CE}$ fractions contained no radioactivity. $95 \%$ of total counts were recovered with this technique. To confirm selectivity of this separation, extracts were also fractionated by TLC on a silica gel G plate (Analtech, Newark, DE) with ether/petroleum ether/acetic acid (20:80:1). Parallel samples were resolved by two-dimensional chromatography on silica gel G HPTLC plates (10 $\times 10 \mathrm{~cm}, \mathrm{E}$. Merck, Gibbstown, NJ) using the method of Rouser et al. (24) to determine whether label was released from specific phospholipid classes. After drying of the plates the spots were visualized in $I_{2}$ vapor and scraped for counting. This method gives good separation of phospholipid classes including phosphatidylinositol (PI) from phosphatidylserine (PS). In preliminary experiments PS, phosphatidic acid and phosphatidyl glycerol combined contained $<2 \%$ of the incorporated label, and released none. In subsequent analyses these PL fractions were ignored.

Determination of PMN phagocytosis of $O Z$. After incubation of PMN with $\mathrm{OZ}$ the reaction was stopped by immersion in an ice bath and $10 \mu \mathrm{l}$ of the cell suspension was removed for cytospin preparation of standard microscope slides (cytospin 2, Shandon Inc., Pittsburgh, 
PA) which were Wrights' stained and examined under high power. At least two samples of $100 \mathrm{PMN}$ were counted and if the counts were not within $5 \%$ of each other an additional sample of $100-200$ cells counted. Random groups were independently examined by a second observer unfamiliar with the results of the first. FITC-labeled OZ was used in some experiments and examined by fluorescence microscopy after trypan blue staining to distinguish adherent from phagocytosed particles.

Cytosolic $P L A_{2}$ assays. PMN were pelleted and resuspended in cavitation buffer containing $50 \mathrm{mM}$ Hepes pH 7.4, $150 \mathrm{mM} \mathrm{NaCl}, 1 \mathrm{mM}$ EDTA, $1 \mathrm{mM}$ EGTA, and an antiprotease cocktail of leupeptin 100 $\mu \mathrm{g} / \mathrm{ml}$, pepstatin $100 \mathrm{ng} / \mathrm{ml}$, aprotinin $100 \mu \mathrm{g} / \mathrm{ml}$, TPCK $100 \mu \mathrm{g} / \mathrm{ml}$, PMSF $2 \mathrm{mM}$, benzamidine $100 \mu \mathrm{M}$, iodoacetamide $1 \mathrm{mM}$, and chymostatin $100 \mu \mathrm{g} / \mathrm{ml}$. The cell mixture was pressurized to $1,000 \mathrm{psi}$ in a cell disruption bomb (Parr Instruments, Moline, IL) for $10 \mathrm{~min}$ and collected through the release valve. Cytosol was collected after centrifugation at $100,000 \mathrm{~g}$ for $30 \mathrm{~min}$.

1-palmitoyl- $\left[2-{ }^{14} \mathrm{C}\right]$ arachidonoyl-phosphatidylcholine and purified $\left[{ }^{3} \mathrm{H}\right] \mathrm{OA}$-labeled phosphatidylethanolamine $(\mathrm{PE})$ was dried under $\mathrm{N}_{2}$. The labeled PE was extracted from Escherichia coli grown in the presence of $\left[{ }^{3} \mathrm{H}\right] \mathrm{OA}$, which results in near-quantitative incorporation of unsaturated fatty acids into the $s n-2$ position of phospholipids (25). The phospholipid mixture was resuspended to a final concentration of $20 \mu \mathrm{M}\left[{ }^{14} \mathrm{C}\right] \mathrm{AA}-\mathrm{PC}\left(2 \times 10^{4} \mathrm{cpm}\right)$ and $20 \mu \mathrm{M}\left[{ }^{3} \mathrm{H}\right] \mathrm{OA}-\mathrm{PE}\left(2 \times 10^{4}\right.$ $\mathrm{cpm}$ ) in $150 \mu \mathrm{l}$ of $20 \mathrm{mM}$ Hepes (pH 7.4) containing $200 \mu \mathrm{M}$ Triton $\mathrm{X}-100,250 \mu \mathrm{g} / \mathrm{ml}$ fatty acid-free BSA, and $70 \%$ ( $\mathrm{vol} / \mathrm{vol}$ ) glycerol, and then sonicated to form mixed micelles $(9,26) .100 \mu$ l of PMN cytosol $\left(4 \times 10^{6} \mathrm{PMN}\right), 2 \mathrm{mM}$ DTT, and $5 \mathrm{mM} \mathrm{CaCl}_{2}$ was added and the mixture incubated at $37^{\circ} \mathrm{C}$ for $30 \mathrm{~min}$ in a shaker. The reaction was stopped by the addition of $500 \mu \mathrm{l}$ methanol containing $25 \mu \mathrm{g} \mathrm{FFA}$, and lipids were extracted by the method of Bligh and Dyer (22). The FFA fractions were recovered after TLC on silica-gel G plates (Analtech) and ether/petroleum ether/acetic acid, 20:80:0.1. The spots were visualized in $\mathrm{I}_{2}$ vapor, scraped, and counted in a scintillation counter.

Immunoprecipitation and immunoblot of $c P L A_{2}$. PMN cytosol was prepared as above and incubated overnight at $4^{\circ} \mathrm{C}$ with $\mathrm{mAb} 1,1,1$ raised against $\mathrm{cPLA}_{2}$ from U937 cells (20). Protein A-sepharose was added for an additional $2 \mathrm{~h}$, centrifuged, and washed three times followed by addition of SDS sample buffer for SDS-PAGE. Samples were electrophoresed on a SDS $/ 7.5 \%$ polyacrylamide gel for $2 \mathrm{~h}$ longer than the time required for the solvent front to elute (27). Western transfer to nitrocellulose was accomplished overnight at $40 \mathrm{~V}$ at $4^{\circ} \mathrm{C}$ followed by immunoblot using polyclonal rabbit serum raised against $\mathrm{CPLA}_{2}$ from U937 cells (20) and the ECL detection system (Amersham Corp., Arlington Hts., IL). Granule-free membrane fractions were prepared as previously described (28).

\section{Results}

Pretreatment of PMN with LPS increases AA release stimulated by $O Z$. To examine the relationship between the release of AA and the LPS-mediated increased production of $\mathrm{LTB}_{4}$, PMN prelabeled with $\left[{ }^{3} \mathrm{H}\right] \mathrm{AA}$ were incubated with or without LPS before addition of OZ. In response to LPS alone, PMN released neither $\left[{ }^{3} \mathrm{H}\right] \mathrm{AA}$ nor $\mathrm{LTB}_{4}(4)$. However, both release of $\left[{ }^{3} \mathrm{H}\right] \mathrm{AA}$ and production of $\mathrm{LTB}_{4}$ were stimulated upon subsequent activation of the PMN with $\mathrm{OZ}$ (Fig. 1). Preincubation with as little as $1 \mathrm{ng} / \mathrm{ml} \mathrm{LPS}$ resulted in increased $\left[{ }^{3} \mathrm{H}\right] \mathrm{AA}$ release with further increases at higher LPS concentrations, reaching a maximum at $10 \mathrm{ng} / \mathrm{ml}$ (Fig. $1 A$ ). The priming effect of LPS was evident over a broad range of OZ concentrations (not shown). Maximal priming effects of LPS on both $\left[{ }^{3} \mathrm{H}\right] \mathrm{AA}$ release and $\mathrm{LTB}_{4}$ production required 45-60 min of preincubation of PMN with LPS before addition of OZ (Fig. 1 $B$ ). In these (and all subsequent) assays, albumin ( $1.5 \%$ ) was added to maximize recovery of released AA. Net recovery of $\left[{ }^{3} \mathrm{H}\right] \mathrm{AA}$ and ${ }^{3} \mathrm{H}$-metabolites was $200-300 \%$ greater in the pres-
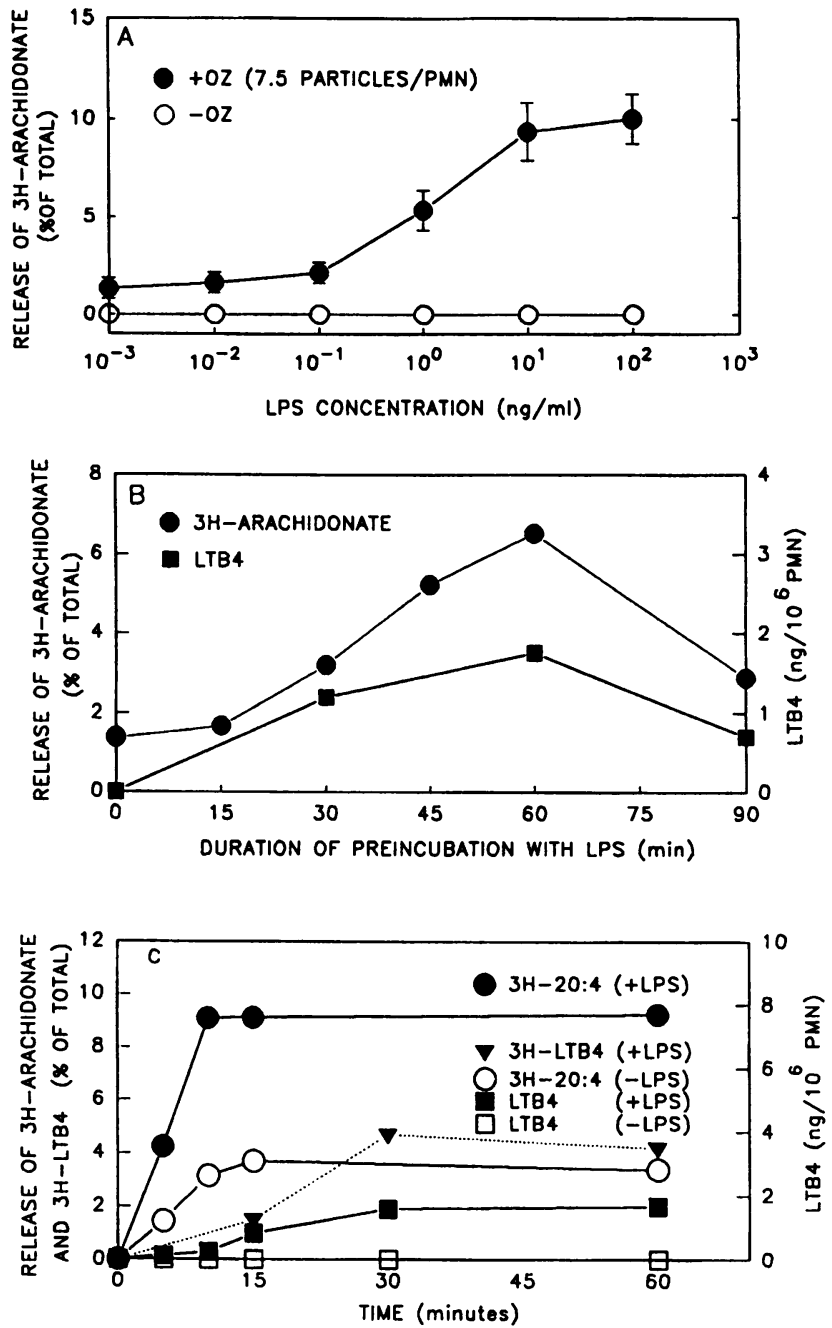

Figure 1. LPS priming of PMN results in enhanced $\left[{ }^{3} \mathrm{H}\right] \mathrm{AA}$ release in response to opsonized zymosan. $(A)$ Effect of preincubating PMN with varying concentrations of LPS. $(B)$ Effect of the duration of preincubation of PMN with LPS $(10 \mathrm{ng} / \mathrm{ml})$. (C) Kinetics of $\left[{ }^{3} \mathrm{H}\right] \mathrm{AA}$ release and $\mathrm{LTB}_{4}$ production by control and LPS-primed $(10 \mathrm{ng} / \mathrm{ml})$ PMN stimulated with OZ. $\left[{ }^{3} \mathrm{H}\right] \mathrm{AA}$-labeled Human PMN were incubated with $S$. minnesota $\operatorname{Re} 595$-LPS for 60 minutes $(A$ and $C$ ) or varied times $(B)$ and then stimulated with opsonized zymosan $(4.5$ particles/PMN) for $15 \min (A$ and $B)$ or for varying times $(C)$ in the presence of $1.5 \%$ albumin. The reaction was stopped by placing the tubes on ice and the cells were pelleted by centrifugation at 25,000 $g$. The supernatant is collected and the percentage of total $\left[{ }^{3} \mathrm{H}\right] \mathrm{AA}$ released was quantitated as described in Methods. $\mathrm{LTB}_{4}$ was determined by HPLC-A270 after extraction on C18 cartridges $(4,19)$. $\left[{ }^{3} \mathrm{H}\right] \mathrm{LTB}_{4}$ was determined as the ${ }^{3} \mathrm{H}$ fractions coeluting with $\mathrm{LTB}_{4}$, $\mathrm{LTB}_{4}-\mathrm{OH}$, or $\mathrm{LTB}_{4}-\mathrm{COOH} . n=8$, in duplicate; Error bars indicate+SEM.

ence of albumin although albumin partially inhibited (20$45 \%$ ) metabolic conversion of $\mathrm{AA}$ to $\mathrm{LTB}_{4}$. Whereas AA release peaked within $10 \mathrm{~min}$ of addition of $\mathrm{OZ}$, leukotrienes (measured radiochemically and by mass) were not detected before $10 \mathrm{~min}$ of incubation and continued to accumulate until 30 min (Fig. $1 C$ ). PMN labeled with $\left[{ }^{14} \mathrm{C}\right] \mathrm{OA}$ instead of $\left[{ }^{3} \mathrm{H}\right] \mathrm{AA}$ and then challenged with $\mathrm{OZ}$ did not release ${ }^{14} \mathrm{C}$-products from either LPS-primed or control cells but did produce $\mathrm{LTB}_{4}$ as assessed by UV absorption-mass detection. Thus, LPS 
primes in PMN, a hydrolytic event that preferentially targets lipids labeled with [ $\left.{ }^{3} \mathrm{H}\right] \mathrm{AA}$.

Role of LBP and CD-14 in LPS priming of PMN. Since LBP amplifies the LPS signal to cells $(3,15,29)$, the effect of LBP on LPS priming of PMN release of $\left[{ }^{3} \mathrm{H}\right] \mathrm{AA}$ and production of $\mathrm{LTB}_{4}$ was examined. Addition of LBP to the cell suspension before LPS, elicited a maximal priming response at levels of LPS as low as $0.1 \mathrm{ng} / \mathrm{ml}$, i.e., a 100-1000-fold increase in the sensitivity of the PMN to LPS priming (Fig. 2). LBP alone did not prime PMN. With increasing LPS concentrations, LBP progressively reduced the time of preincubation needed to achieve maximal stimulation of $\left[{ }^{3} \mathrm{H}\right] \mathrm{AA}$ release after addition of $\mathrm{OZ}$ (from $60 \mathrm{~min}$ without LBP to $\leq 15 \mathrm{~min}$ with LBP, 0.75 $\mu \mathrm{g} / \mathrm{ml}$ and $100 \mathrm{ng} \mathrm{LPS} / \mathrm{ml}$; Fig. 2). The transient nature of LPS-priming was observed at all doses of LPS (with and without LBP) (Figs. 1 and 2). The effects of LBP on LPS-priming of $\mathrm{LTB}_{4}$ production parallel those on $\left[{ }^{3} \mathrm{H}\right] \mathrm{AA}$ release (not shown). LPS priming (with and without LBP) was completely inhibited when a neutralizing monoclonal antibody to CD14 was added before LPS but not when this antibody was added 5 min after LPS (with and without LBP) (Fig. 3). Unrelated, isotype-matched control monoclonal antibody had no inhibitory effect. Mabs altered the effect of $\mathrm{OZ}$ on PMN and PMA was therefore used as the second stimulant for these studies.

LPS stimulates uptake of OZ by PMN. Ingestion of bacteria by PMN is increased by pretreatment with LPS (17). The stimulated $\left[{ }^{3} \mathrm{H}\right]$ AA metabolism triggered by addition of $\mathrm{OZ}$ stimulation as a second stimulus after LPS priming might therefore be secondary to enhanced phagocytic activity.

PMN pretreated with LPS (10 $\mathrm{ng} / \mathrm{ml}$ ) ingested more $\mathrm{OZ}$

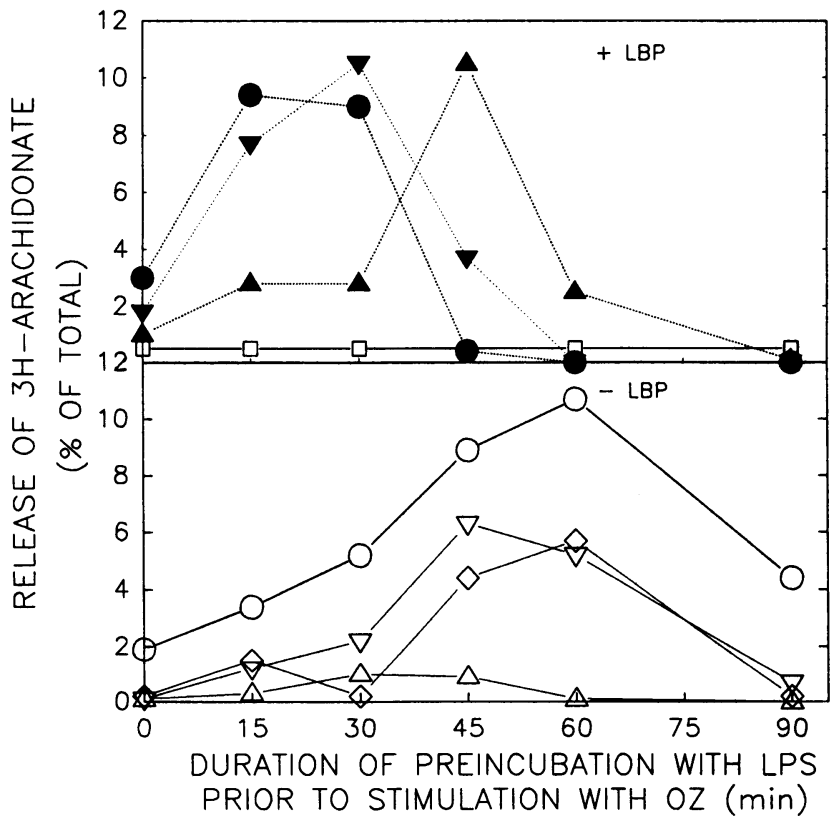

Figure 2. LBP enhances and accelerates the effect of LPS-priming on PMN metabolism of $\left[{ }^{3} \mathrm{H}\right] A A$. $\left[{ }^{3} \mathrm{H}\right]$ AA-labeled PMN were incubated in the presence of LPS as in Fig. 1, for the time shown. The closed symbols represent $\mathrm{LBP}=0.75 \mu \mathrm{g} / \mathrm{ml}+\mathrm{LPS}$ and open symbols represent LPS alone. LPS $=0(\bullet), \mathrm{LPS}=0.1 \mathrm{ng} / \mathrm{ml}(\Delta), \mathrm{LPS}=1 \mathrm{ng} / \mathrm{ml}$ $(\diamond), \mathrm{LPS}=10 \mathrm{ng} / \mathrm{ml}(\nabla), \mathrm{LPS}=100 \mathrm{ng} / \mathrm{ml}(\bullet)$. PMN were then stimulated with $\mathrm{OZ}$ (4.5 particles/PMN) and the release of $\left[{ }^{3} \mathrm{H}\right] \mathrm{AA}$ was determined as in Fig. 1. LBP alone does not effect PMN release of $\left[{ }^{3} \mathrm{H}\right] \mathrm{AA}$ or the response to $\mathrm{OZ}$.

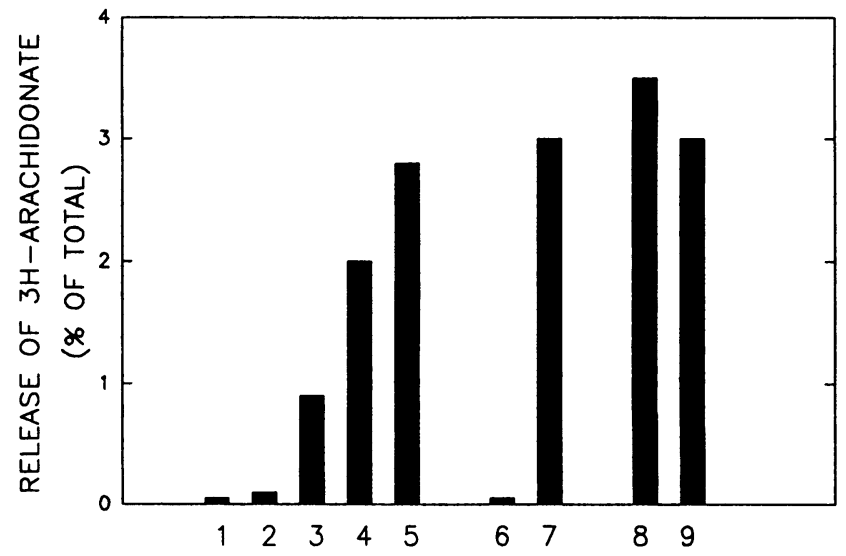

Figure 3. Anti-CD14 mAbs block LPS priming of PMN only if added before LPS. $\left[{ }^{3} \mathrm{H}\right]$ AA labeled PMN were incubated with LPS for 45 $\min$ at $37^{\circ} \mathrm{C}$ as in Fig. 1. Column $1, \mathrm{LPS}=0 ; 2, \mathrm{LPS}=0.1 \mathrm{ng} / \mathrm{ml}$; $3, \mathrm{LPS}=1.0 \mathrm{ng} / \mathrm{ml} ; 4, \mathrm{LPS}=10 \mathrm{ng} / \mathrm{ml}$; and $5-9, \mathrm{LPS}=100 \mathrm{ng} / \mathrm{ml}$. Anti-CD14 mAbs (MY4, $2.5 \mu \mathrm{g} / \mathrm{ml}$ ) were added to PMN before LPS (6) or $5 \mathrm{~min}$ after LPS (7). Isotype control Mabs $\left(\mathrm{IgG}_{2 \mathrm{~B}}, 2.5 \mu \mathrm{g} / \mathrm{ml}\right)$ were added prior to LPS (8) or $5 \mathrm{~min}$ after LPS (9). PMN were then incubated with PMA $0.03 \mu \mathrm{g} / \mathrm{ml}$ for $15 \mathrm{~min}$ and the release of $\left[{ }^{3} \mathrm{H}\right] A A$ quantitated as in Methods. The results of a single experiment, in duplicate, representative of three separate experiments is shown.

than untreated $\mathrm{PMN}$ over a wide range of $\mathrm{OZ}$ concentrations (Fig. 4). Uptake of $\mathrm{OZ}$ both in the presence and absence of LPS was complete within $5 \mathrm{~min}$ (not shown). Uptake of unopsonized zymosan is $<25 \%$ of $\mathrm{OZ}$ and was not increased by pretreatment with LPS (not shown). That increased uptake represented ingestion rather than adherence was verified as described in Methods by fluorescent microscopy of LPS-pretreated and control PMN after incubation with FITC-labeled OZ.

In contrast to the requirement for preincubation with LPS for the priming of $\left[{ }^{3} \mathrm{H}\right] \mathrm{AA}$ and $\mathrm{LTB}_{4}$ release, no preincubation was necessary for the LPS effect on uptake of OZ, nor was stimulation diminished by longer preincubation with LPS (Fig. $4 B$ ). The differences in the magnitude (Fig. $4, A$ and $C$ ) and time dependence of these two effects of LPS suggest that priming of AA metabolism includes effects on the cellular AA metabolic machinery that are distinct from effects on phagocytosis. Moreover, LPS priming of $\left[{ }^{3} \mathrm{H}\right] \mathrm{AA}$ release was also observed with non-phagocytic (soluble) stimuli including the $\mathrm{Ca}^{2+}$ ionophore A23187 and PMA (Table I). In contrast to $\mathrm{OZ}$ and A23187 as stimuli, PMA triggered $\left[{ }^{3} \mathrm{H}\right] \mathrm{AA}$ release but no production of $\left[{ }^{3} \mathrm{H}\right] \mathrm{LTB}_{4}$. Mass determination of AA release by gas chromatography of control and PMA stimulated PMN, with and without LPS priming, confirmed the results shown with $\left[{ }^{3} \mathrm{H}\right] \mathrm{AA}$, i.e., LPS alone had no effect on AA release and priming resulted in a two- to threefold increase in AA release from PMA ( $1 \mu \mathrm{g} / \mathrm{ml}$ ) stimulated PMN. $\alpha$-phorbol-diacetate ( 1 $\mu \mathrm{g} / \mathrm{ml})$ treatment of PMN results in no release of $\left[{ }^{3} \mathrm{H}\right] \mathrm{AA}$ from control or LPS-primed PMN (not shown). Another stimulus of many PMN responses, FMLP, stimulated little or no $\left[{ }^{3} \mathrm{H}\right]$ AA release (and no production of $\mathrm{LTB}_{4}$ ) from either control or LPS-primed PMN (Table I).

Released AA stems from phospholipid. The source of $\left[{ }^{3} \mathrm{H}\right] \mathrm{AA}$ released from LPS-primed and unprimed PMN was determined by separating extracted lipids, before and after stimulation with OZ or PMA. Table II shows the distribution of 

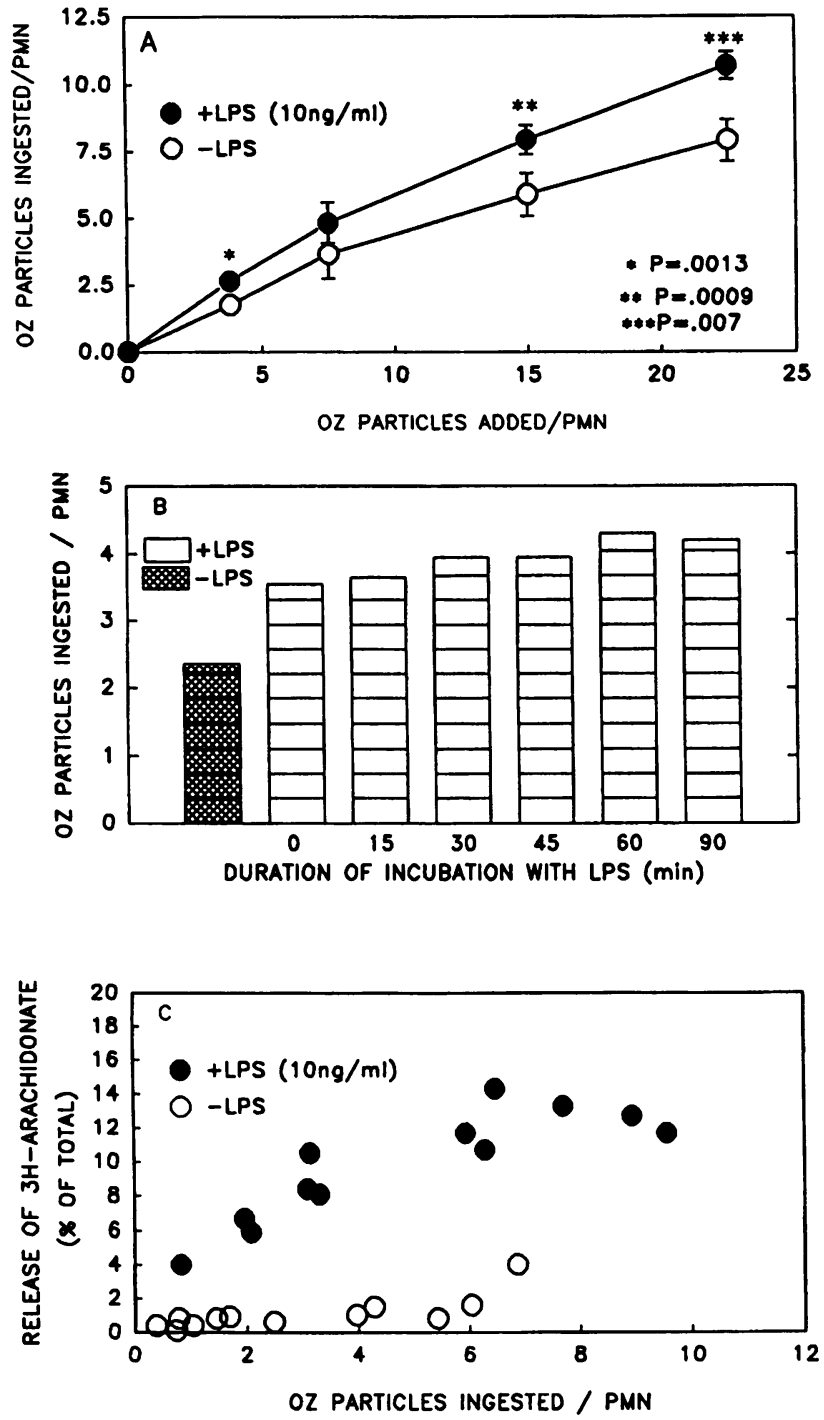

Figure 4. PMN exposed to LPS ingest greater amounts of $\mathrm{OZ}$ particles. Uptake of $\mathrm{OZ}$ was determined by light microscopy after cytospin and staining with a modified Wright's stain (Dif-Quik). Cell-associated $\mathrm{OZ}$ was confirmed as intracellular by fluorescent microscopy of fluoroscein-isothiocyanate labeled $\mathrm{OZ}$ in the presence of trypan blue dye which quenches the fluorescence of extracellular OZ. Uptake of OZ by both LPS-primed and control PMN reaches a maximum within $5 \mathrm{~min}$ (not shown). PMN were incubated with LPS for $60 \mathrm{~min}$ $(A$ and $C$ ) and then stimulated with opsonized zymosan (4.5 particles/PMN; $B$ and $C$ ) for $15 \mathrm{~min}$. The release of $\left[{ }^{3} \mathrm{H}\right] \mathrm{AA}(C)$ was determined as in Fig. 1. $n=8$ in duplicate, for $A$ and $B$, Error bars $= \pm$ SEM. Panel $C$ is a single experiment in duplicate, representative of three separate experiments.

incorporated $\left[{ }^{3} \mathrm{H}\right] \mathrm{AA}$ among the main lipid classes. LPS, alone, did not affect this distribution. Approximately $50 \%$ of the incorporated $\left[{ }^{3} \mathrm{H}\right] \mathrm{AA}$ was in phospholipids, $60 \%$ of which was in PI, 25\% in PC, and 15\% in PE. Loss of label from primed and unprimed PMN after stimulation with OZ (or PMA, not shown) was restricted to these three phospholipid species in proportion to their relative radioactivities (and was accompanied by a corresponding accumulation of $\left[{ }^{3} \mathrm{H}\right] \mathrm{AA}$ and metabolites). Thus, the lipolytic step involved in AA release is most likely attributable to a phospholipase $A_{2}$ with preference for $\left[{ }^{3} \mathrm{H}\right] \mathrm{AA}$ vs $\left[{ }^{14} \mathrm{C}\right] \mathrm{OA}$ labeled phospholipids.
Table I. $\left[{ }^{3} H\right] A A$ Release by LPS-primed PMN in Response to Particulate and Soluble Stimuli

\begin{tabular}{|c|c|c|c|c|}
\hline \multirow[b]{2}{*}{ Stimulant } & \multicolumn{2}{|c|}{$\begin{array}{l}\text { Percent release of total } \\
{\left[{ }^{3} \mathrm{H}\right] \mathrm{AA}\left(\left[{ }^{3} \mathrm{H}\right] \mathrm{LTB}_{4}\right)}\end{array}$} & \multicolumn{2}{|c|}{$\begin{array}{c}\text { LTB }_{4} \text { Production } \\
\left.\text { (ng/10 } 10^{6} \mathrm{PM}\right)\end{array}$} \\
\hline & -LPS & +LPS & -LPS & + LPS \\
\hline No stimulant & 0 & 0 & 0 & 0 \\
\hline $\mathrm{OZ}(750 \mu \mathrm{g} / \mathrm{ml})$ & $2.9(0)$ & $7.9(2.8)$ & 0 & 1.9 \\
\hline PMA $(1 \mu \mathrm{g} / \mathrm{ml})$ & $16.6(0)$ & $26.0(0.5)$ & 0 & 0.2 \\
\hline A23187 $(0.1 \mu \mathrm{g} / \mathrm{ml})$ & $11.8(4.2)$ & $24.4(8.8)$ & 8 & 14.6 \\
\hline FMLP $\left(10^{-6} \mathrm{M}\right)$ & 0 & $1.7(0)$ & 0 & 0 \\
\hline
\end{tabular}

$\left[{ }^{3} \mathrm{H}\right]$ arachidonate labeled PMN were incubated \pm LPS $(10 \mathrm{ng} / \mathrm{ml})$ in the presence of $1.5 \%$ albumin for 60 min then stimulated for $15 \mathrm{~min}$ with various stimuli as shown. The release of $\left[{ }^{3} \mathrm{H}\right] \mathrm{AA}$ is determined as in Fig. 1. The means of five experiments, in duplicate, \pm SEM are shown. Stimulation of $\left.{ }^{3} \mathrm{H}\right] A A$ release by PMN (with or without LPS-priming) does not require extracellular calcium when PMA is used as an activating agent.

AA-selective PLA $A_{2}$ activity in cytosol of PMN is increased after LPS priming. Many cells, including PMN, contain a cytosolic AA-selective PLA $\mathrm{P}_{2}$ activity $(9,30)$. To determine the effect of LPS priming on this activity, cytosolic fractions were isolated from PMN before and after treatment with LPS. Table III shows that cytosolic fractions of LPS-primed PMN hydrolyzed two- to threefold more 1-palmitoyl- $\left[2-{ }^{14} \mathrm{C}\right]$ arachidonoyl PC than did similar fractions from unprimed cells. This activity was resistant to DTT and strictly dependent on added $\mathrm{Ca}^{2+}$. No $\mathrm{PLA}_{2}$ activity was detected against $\left[{ }^{3} \mathrm{H}\right] \mathrm{OA}$ labeled phosphatidylethanolamine, a substrate that is readily hydrolyzed by type II PLA ${ }_{2}$ s from various sources, including PMN and inflammatory fluids $(13,31-33)$.

Phosphorylation of $C P L A_{2}$ during LPS priming. These findings suggest that a $\mathrm{CPLA}_{2}$ with preference for AA-containing phospholipids $(27,30)$ is effected during LPS-priming of PMN.

To explore this possibility further, we examined the electrophoretic mobility during SDS-PAGE of an $85-\mathrm{kD} \mathrm{cPLA}_{2}$ recov-

Table II. Distribution of $\left[{ }^{3} H\right] A A$ in PMN Lipids Before and After LPS Priming and Stimulation with $O Z$

\begin{tabular}{lrrrr}
\hline & \multicolumn{4}{c}{ Percentage of $\left.{ }^{3} \mathrm{H}\right] \mathrm{HA}$ present by lipid class } \\
\cline { 2 - 4 } & \multicolumn{4}{c}{ Treatment of PMN } \\
\cline { 2 - 5 } & \multicolumn{1}{c}{ Control } & \multicolumn{1}{c}{ LPS } & OZ & LPS;OZ \\
\hline FFA & $3.1 \pm 0.6$ & $3.0 \pm 0.5$ & $7.0 \pm 0.6^{*}$ & $20.3 \pm 2.0^{*}$ \\
PL & $52.2 \pm 2.0$ & $51.1 \pm 2.6$ & $42.2 \pm 1.6^{*}$ & $30.4 \pm 1.9^{*}$ \\
TG & $37.0 \pm 3.0$ & $37.2 \pm 1.7$ & $38.6 \pm 3.2$ & $37.9 \pm 3.7$ \\
DG & $2.6 \pm 0.3$ & $2.2 \pm 0.2$ & $3.1 \pm 0.5$ & $3.4 \pm 0.3$ \\
MG & $6.0 \pm 1.5$ & $7.4 \pm 1.6$ & $9.0 \pm 1.4$ & $8.0 \pm 1.1$ \\
\hline
\end{tabular}

[ $\left.{ }^{3} \mathrm{H}\right]$ AA-labeled PMN were incubated with or without LPS $=10 \mathrm{ng} /$ $\mathrm{ml}$, for $60 \mathrm{~min}$ and then with or without $\mathrm{OZ}$ for $15 \mathrm{~min}$ in the presence of $1.5 \%$ albumin. $\mathrm{CHCl}_{3} / \mathrm{MeOH}$ extracts were prepared and the lipids separated on amino-propyl cartridges (23). The results represent the means $\pm \mathrm{SEM}$ of five experiments. * Differs significantly from column $1\left(P<0.05\right.$, student's paired t-test). ${ }^{\ddagger}$ Differs significantly from columns 1,2 , and 3 . 
Table III. cPLA $A_{2}$ Activity Is Increased in Cytosolic Fractions of LPS-treated PMN

\begin{tabular}{lc}
\hline & {$\left[{ }^{14} \mathrm{C}\right]$ AA released } \\
\hline & $c p m$ \\
Control PMN & $402 \pm 43$ \\
PMN primed with LPS $100 \mathrm{ng} / \mathrm{ml}$ for $45 \mathrm{~min}$ & $872 \pm 117$ \\
PMN primed with LPS $100 \mathrm{ng} / \mathrm{ml}+$ LBP for & \\
45 min & $1047 \pm 32$ \\
\hline
\end{tabular}

Cytosolic fractions of LPS treated and control PMN were collected as described in Methods. After addition of DTT $(2 \mathrm{mM})$ the mixture was incubated for $15 \mathrm{~min}$ with 1-palmitoyl- $\left[{ }^{14} \mathrm{C}\right]$ arachidonoyl-PC and $\left[{ }^{3} \mathrm{H}\right] \mathrm{OA}-\mathrm{PE}$ in $20 \mathrm{mM}$ Hepes, pH 7.4, containing $200 \mu \mathrm{M}$ Triton $\mathrm{X}-100,250 \mu \mathrm{g} / \mathrm{ml} \mathrm{BSA}$, and $70 \%$ glycerol (vol/vol) which had been sonicated to form mixed micelles (9). The reaction was stopped by addition of $\mathrm{MeOH}$ and free fatty acids were quantitated by scintillation counting after lipid extraction and TLC as described in Methods. (No ${ }^{3} \mathrm{H}$ release was detected, data not shown). Means \pm SEM are shown, $n=5$ in duplicate for columns 1 and 2 and $n=3$ in duplicate for column 3. $P<0.002$ by students paired $t$-test for comparison of column 1 with column 2 or 3 . Comparison of column 2 with $3, p=$ NS.

ered by immunoprecipitation from $\mathrm{N}_{2}$ cavitates of LPS-primed and control PMN. The electrophoretic mobility of this $\mathrm{CPLA}_{2}$ transfected into $\mathrm{CHO}$ cells is reduced when the cells are stimulated and AA release is triggered (27). This "gel-shift" is linked to phosphorylation and reversed by phosphatase treatment (27). Fig. 5 shows that LPS treatment of PMN also causes a "gel-shift" of an 85-kD protein species reactive with anticPLA $_{2}$ antiserum. This gel-shift does not occur in PMN incubated with anti-CD14 Mabs before LPS treatment (not shown). Treatment of the immunoprecipitated protein with alkaline phosphatase before electrophoresis converts the protein back to a faster migrating form (Fig. 5, top; lanes 5 and 6 ). The extent of apparent phosphorylation of the cPLA ${ }_{2}$ depends on the dose of LPS and time of LPS treatment ( with or without LBP) in a manner that parallels the initial phase of priming of $\left[{ }^{3} \mathrm{H}\right]$ AA release by LPS (compare Figs. 1, 2, and 5). However, in contrast to the transient effect of LPS-priming of AA-metabolism in intact PMN, the altered cPLA ${ }_{2}$-gel mobility (Fig. 5, top, lane 7, and bottom, lane 9) and the enhanced cytosolic PLA $_{2}$ activity persist (Table III). Both $\mathrm{CPLA}_{2}$ species were recovered only from cytosolic fractions ( $100,000-g$ supernatant) when sedimentation of PMN cavitates was carried out in $1 \mathrm{mM}$ EGTA (Fig. 6; lanes 1, 2, 5, and 6). By contrast, both species were lost from the cytosolic fractions and recovered in purified PMN granule-free membrane fractions when these two fractions were mixed and reseparated by centrifugation in the presence of $10 \mu \mathrm{M}$ free $\mathrm{Ca}^{2+}$ (lanes 3, 4, 7, and 8$)(20,34)$. At 100 nM free $\mathrm{Ca}^{2+}$ essentially no cPLA ${ }_{2}$ associates with the membranes and at $300 \mathrm{nM}$ free $\mathrm{Ca}^{2+} 80-90 \%$ is membrane associated (not shown) similar to what has been previously described with U937 cell derived $\mathrm{CPLA}_{2}$ (20).

Effect of staurosporine on PMA-mediated cPLA $A_{2}$ phosphorylation and activation of $A A$ (with and without $L P S$ priming) in $P M N$. Table I shows that PMA activates $\left[{ }^{3} \mathrm{H}\right] \mathrm{AA}$ release in PMN. In contrast, PMA primes but causes little or no direct activation of $\left[{ }^{3} \mathrm{H}\right] \mathrm{AA}$ release in $\mathrm{CHO}$ cells overexpressing $\mathrm{cPLA}_{2}(35)$. To further explore the apparent differences in
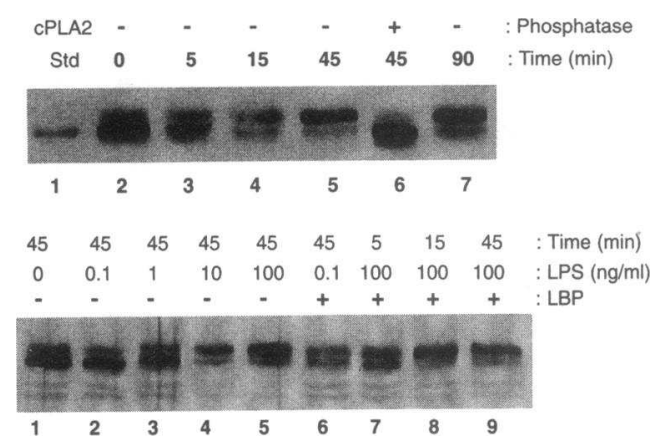

Figure 5. PMN cPLA 2 is phosphorylated in response to LPS. $2 \times 10^{7}$ PMN were incubated with or without LPS then disrupted by $\mathrm{N}_{2}$ cavitation. PMN cPLA 2 was immunoprecipitated from cytosolic fractions ( $100,000 \mathrm{~g}$ supernatant) with Mab directed against $\mathrm{CPLA}_{2}$ from U937 cells and run on $20 \times 20-\mathrm{cm}$ gels containing $7.5 \%$ acrylamide; $0.1 \%$ bis-acrylamide. Gels were run at $125 \mathrm{~V}$ through the stacking gel then $250 v$ for $5 \mathrm{~h}$ using the Laemmli buffer system (54). Proteins were transferred from gel to nitrocellulose by conventional procedure and reacted subsequently with polyclonal antiserum directed against U937 $\mathrm{CPLA}_{2}$ and detected with the Amersham ECL detection system. The results of a single experiment are shown which are representative of four separate experiments. Top: Lane 1 is purified $\mathrm{CPLA}_{2}$ from U937 cells ( $40 \mathrm{ng}$ ); lane 2 is the cytosolic fraction from control PMN, lanes 3-7 are cytosolic fractions from PMN treated with $100 \mathrm{ng}$ LPS $/ \mathrm{ml}$ for times as shown. Lane 6 protein was incubated for $30 \mathrm{~min}$ at $37^{\circ} \mathrm{C} \mathrm{pH} 9.0$ with alkaline phosphatase prior to SDS-PAGE. Bottom: Lane 1 is the cytosolic fraction from control PMN, lanes 2-9 are cytosolic fractions from PMN treated with varied concentrations of LPS as indicated above each lane for the times shown. The presence or absence of LBP $0.75 \mu \mathrm{g} / \mathrm{ml}$ (lanes 6-9) is indicated by \pm above each lane (+ lanes 6-9).

regulation of [ $\left.{ }^{3} \mathrm{H}\right] \mathrm{AA}$ release in these two cell types, the effects of staurosporine, a putative protein kinase $\mathrm{C}$ inhibitor were tested in PMN. In CHO cells, staurosporine fully inhibits the effects of PMA on both $\left[{ }^{3} \mathrm{H}\right] \mathrm{AA}$ release and phosphorylation (e.g., gel shift) $(27,35)$. In PMN, by contrast, staurosporine

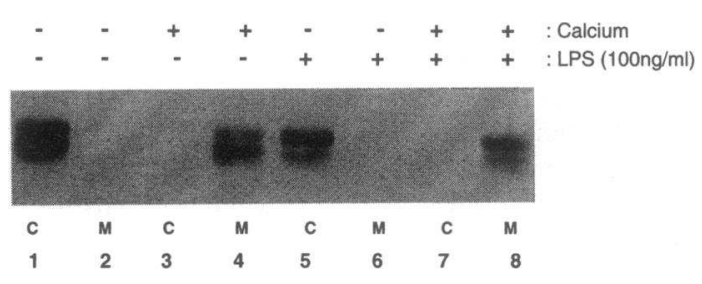

Figure 6. PMN cPLA ${ }_{2}$ associates with the membrane fraction in the presence of calcium. LPS-primed and control PMN were disrupted by $\mathrm{N}_{2}$ cavitation in the presence of $1 \mathrm{mM}$ EGTA and centrifuged on a cushion of $40 \%$ sucrose at $100,000 \mathrm{~g}$ for $1 \mathrm{~h}$. The cytosol was removed and the membranes (the fraction layered on the sucrose cushion ) were collected, rinsed and resuspended in $50 \mathrm{mM}$ Tris $/ \mathrm{HCl}, \mathrm{pH}$ 7.4. Membranes and cytosol were recombined and calcium was added to one-half of each sample. After centrifugation the pellet and supernatant were again separated and $\mathrm{CPLA}_{2}$ was immunoprecipitated and run on SDS-PAGE as described in Methods. Lanes 1-4 are from control PMN and lanes 5-8 are from LPS-primed PMN. The presence or absence of added calcium (calculated free calcium $10 \mu \mathrm{M}$ ) is indicated with \pm above each lane. $C$ and $M$ below each lane indicate whether the sample is the cytosol or membrane fraction. No cPLA was detected in crude membrane fractions (unfractionated cell pellet after $\mathrm{N}_{2}$ cavitation ). 

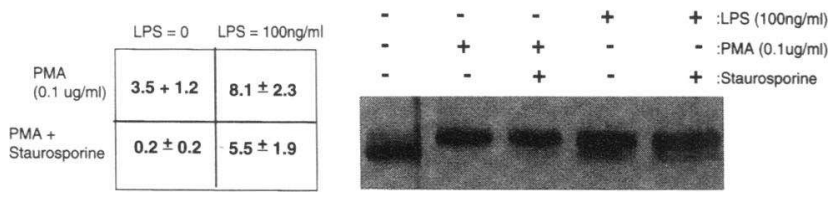

Figure 7. The effects of PMA on PMN, with or without LPS, involve staurosporine sensitive and insensitive pathways. PMN were incubated at $37^{\circ} \mathrm{C}$ in the presence or absence of staurosporine $(1 \mu \mathrm{g} / \mathrm{ml})$ for $15 \mathrm{~min}$ and then in the presence or absence of LPS $100 \mathrm{ng} / \mathrm{ml}$ for $45 \mathrm{~min}$ followed by stimulation with PMA $(0.1 \mu \mathrm{g} / \mathrm{ml})$ for $15 \mathrm{~min}$. $\left[{ }^{3} \mathrm{H}\right] \mathrm{AA}$ release was determined as [cpm (supernatant $\mathrm{x}$ ) - cpm (supernatant of unstimulated cells)/(CPM (total) - CPM ( supernatant of unstimulated cells)) ] $\times 100$ and is shown in the left panel and immunoblots of $\mathrm{CPLA}_{2}$ are shown in the right panel. Lane 1 represents control PMN. PMN treated with LPS, PMA, and staurosporine are indicated with \pm over each lane.

inhibits PMA stimulated release of $\left[{ }^{3} \mathrm{H}\right] \mathrm{AA}$ by PMN but not the gel shift of $\mathrm{CPLA}_{2}$ (Fig. 7). Moreover, even in the presence of staurosporine, pretreatment of PMN with LPS permits (near) maximal activation of $\left[{ }^{3} \mathrm{H}\right] \mathrm{AA}$ release upon addition of PMA (Fig. 7). $\alpha$-phorbol-diacetate $(1 \mu \mathrm{g} / \mathrm{ml})$ treatment of PMN results in neither $\left[{ }^{3} \mathrm{H}\right]$ AA release or the gel shift of $\mathrm{CPLA}_{2}$ (not shown).

\section{Discussion}

Incubation of PMN in vitro with minute quantities of LPS provokes a range of immediate and delayed responses that reflect the primary involvement of this cell in vivo in the defense mounted by the host against invading Gram-negative bacteria and/or its envelope LPS. Among the many PMN functions elicited or amplified by exposure to LPS are generation of reactive oxygen derivatives (21) and $\mathrm{LTB}_{4}(4)$, expression on the cell surface of receptors for components of complement and other signals $(15,16)$, and enhanced phagocytosis of bacteria (17). In this study we have focussed on the further analysis of the process that provides AA for the generation of the potent inflammatory mediator $\mathrm{LTB}_{4}$.

We show that treatment of PMN with LPS alone causes neither appreciable release of $\left[{ }^{3} \mathrm{H}\right] \mathrm{AA}$ from esterified lipid pools (Fig. 1) nor production of $\mathrm{LTB}_{4}$ or $\mathrm{LTB}_{4}$ metabolites (4). Although the distribution in esterified lipid pools of $\left[{ }^{3} \mathrm{H}\right]$ AA derived from extracellular sources differs from that of endogenous pools of esterified AA $(36,37)$, no release of AA from endogenous pools in PMN has been described without concomitant measurable deacylation of radiolabeled AA pools $(36,37)$. This was confirmed in our investigations by gas chromatography of supernatants from LPS-primed and control cells with and without PMA (not shown). The increased production by LPS-pretreated PMN of $\mathrm{LTB}_{4}$ that is triggered by addition of $\mathrm{OZ}$ parallels increased release of [ $\left.{ }^{3} \mathrm{H}\right] \mathrm{AA}$ (Fig. 1). Under all conditions studied, the requirements for formation of $\mathrm{LTB}_{4}$ were the same whether measured radiochemically or by mass suggesting that metabolism of $\left[{ }^{3} \mathrm{H}\right] \mathrm{AA}$ and endogenous (unlabeled) AA was similar. Dose and time requirements for LPS priming of $\left[{ }^{3} \mathrm{H}\right] \mathrm{AA}$ release and $\mathrm{LTB}_{4}$ formation (triggered by $\mathrm{OZ}$ ) were virtually identical suggesting that under these experimental conditions the lipolytic step governs $\mathrm{LTB}_{4}$ formation. Apparently this is also the case in FMLP-treated
PMN that do not release $\left[{ }^{3} \mathrm{H}\right] \mathrm{AA}$ and do not generate $\mathrm{LTB}_{4}$ from endogenous AA (labeled or unlabeled) stores (Table I) but can metabolize exogenously added $A A$ to $\mathrm{LTB}_{4}$ (38). In contrast, PMA-treated PMN (with and without LPS priming) actively release $\left[{ }^{3} \mathrm{H}\right] \mathrm{AA}$ but little or no $\left[{ }^{3} \mathrm{H}\right] \mathrm{LTB}_{4}$ (Table I), indicating that under these conditions biochemical mechanisms mediating AA release and metabolism to leukotrienes are dissociated.

PMN have long been known to contain various $\mathrm{PLA}_{2}$ activities $(12,30,39)$. One activity that is primarily associated with the cytoplasmic granules and subcellular membrane fractions (12), has been best characterized in rabbit PMN, where it has been shown to be a 14-kD type-II (nonpancreatic) $\mathrm{PLA}_{2}$ (13). This enzyme participates in the digestion of bacterial phospholipids during phagocytosis (33), a role consistent with its presence in the granules of the PMN. In contrast, no role of this $\mathrm{PLA}_{2}$ in the turnover of endogenous phospholipids and specifically AA-containing phospholipids has yet been established.

On the other hand, several of our findings now strongly suggest that a cytosolic PLA 2 preferring [ ${ }^{3} \mathrm{H}$ ]AA-labeled phospholipids participates in the lipolytic event that is primed by LPS: $(a)$ the apparent specificity of the lipolysis for AA-containing phospholipids; $(b)$ the remarkable synchrony of the phosphorylation (gel shift) of the $\mathrm{CPLA}_{2}$ and the priming for AA release; and $(c)$ the similar dependence of these two sequelae of LPS pretreatment on LPS concentration both in the presence and absence of LBP (Figs. 2 and 5). The fact that LPS treatment does not activate AA release in intact $P M N$ is consistent with recent studies of $L$ in et al. who have shown a similar separation of phosphorylation and activation of the $\mathrm{CPLA}_{2}$ overexpressed in $\mathrm{CHO}$ cells (27). These investigators have proposed that while phosphorylation of $\mathrm{CPLA}_{2}$ is necessary for maximal activation, hydrolytic activity is expressed only if the enzyme associates with its substrate in an additional, $\mathrm{Ca}^{2+}$-dependent, step (35). As in that study, we have shown that phosphorylation of the $\mathrm{CPLA}_{2}$ in PMN is associated with a two- to threefold increase in calcium-requiring hydrolytic activity of cytosolic fractions (containing all recovered $\mathrm{CPLA}_{2}$ ) toward 1palmitoyl- $\left[{ }^{14} \mathrm{C}\right]$ arachidonoyl PC (Table III). Because LPS treatment of PMN causes little (40) or no (4) increase in $\mathrm{Ca}_{\mathrm{i}}{ }^{2+}$, we speculate that activation of $\mathrm{AA}$ release awaits a second stimulus (e.g., OZ, A23187) that triggers increased $\mathrm{Ca}_{i}{ }^{2+}(4)$ and, hence, $\mathrm{Ca}^{2+}$-dependent translocation of the $\mathrm{CPLA}_{2}$ to a membrane (substrate) site where hydrolysis occurs. Such a scheme is consistent with the inability of FMLP to activate $\left[{ }^{3} \mathrm{H}\right] \mathrm{AA}$ release (with or without LPS priming) apparently because the increase in $\mathrm{Ca}_{\mathrm{i}}{ }^{2+}$ triggered by FMLP is insufficient to meet the requirements for $\mathrm{CPLA}_{2}$ activation $(41,42)$.

However, this scheme does not readily explain the potent activating effects of PMA in PMN (Table I) and the ability of LPS to further sensitize PMN to PMA. PMA treatment of CHO cells overexpressing $\mathrm{CPLA}_{2}$ and LPS treatment of PMN produce similar effects: phosphorylation leading to a gel shift of cPLA ${ }_{2}$ but no change in intracellular calcium; and priming but little or no activation of AA release (27). All effects of PMA on cPLA $_{2}$ and AA release in CHO cells are blocked by staurosporine, an inhibitor of protein kinase $\mathrm{C}(\mathrm{PKC})$, indicating that, as expected, this enzyme is the primary target of PMA action and upstream of a mitogen-activated protein kinase 2 in CHO cells (35). A different picture emerges when PMN are treated with staurosporine. In these cells this agent prevents the activation by PMA of AA release but does not block the gel-shift of 
cPLA $_{2}$. Staurosporine also does not block the gel-shift in LPStreated PMN. However, in contrast to the blocking by staurosporine of AA release when PMN are treated with PMA alone, PMA added subsequent to LPS treatment allows full activation of AA release (Fig. 7). These findings suggest the following: $(a)$ Because PMA treatment does not mobilize $\mathrm{Ca}_{i}{ }^{2+}$ in PMN (43, 44) the ability of PMA to activate AA release in PMN (with or without LPS priming) suggests an alternative mechanism of activation of AA release in PMN, primed by LPS, either lowering the $\mathrm{Ca}^{2+}$ requirement of $\mathrm{CPLA}_{2}$ or perhaps involving a different lipolytic system. (b) The gel shift of CPLA $_{2}$ induced by PMA in the presence of staurosporine implies the presence of a PMA-sensitive, staurosporine-insensitive kinase in PMN but not in CHO cells. The fact that staurosporine blocks activation by PMA of AA release but not the cPLA $_{2}$ gel shift in PMN further suggests that PMA action in PMN involves both staurosporine-sensitive (?PKC) and staurosporine-resistant effects. The $\mathrm{cPLA}_{2}$ contains multiple potential phosphorylation sites including consensus sites for PKC $(20,44)$ and several potential mitogen-activated protein kinase 2 sites including ser- 505 $(20,35)$. The gel shift of $\mathrm{CPLA}_{2}$ in $\mathrm{CHO}$ cells requires phosphorylation of ser-505 (35). Hence, the different effects of PMA on AA metabolism by CHO cells and by PMN could reflect differences in the sites of phosphorylation of $\mathrm{CPLA}_{2}$ induced by PMA in these different cell types. Further, although the similar CPLA $_{2}$ gel shifts produced in LPS- or PMA-treated PMN and PMA-treated CHO cells strongly suggest that in PMN ser-505 of cPLA A $_{2}$ also phosphorylated by mitogen-activated protein kinase 2 , the different effects of staurosporine on the actions of LPS and PMA alone and in combination imply additional and as yet undefined biochemical events underlying LPS (PMA-triggered) regulation of phospholipolysis.

The complexity of LPS action is widely appreciated (1). Nevertheless, recent findings in many laboratories have revealed that the diverse effects of LPS on certain host cells including PMN appear to emanate from interactions of LPS with a single membrane protein, CD14, particularly after interaction of LPS in the extracellular medium with $\operatorname{LBP}(3,15,46)$. We provide further evidence of the primary role of CD14 in LPS signaling with or without LBP. The initial engagement of LPS with CD14 is very rapid ( $\leq 5 \mathrm{~min}$ even in the absence of LBP; Fig. 3) and hence the time dependence of LPS priming of AA metabolism reflects mainly post-CD14 signal transduction events presumably involving a cascade of kinase activation and phosphorylation steps. CD14 is a GPI-linked membrane protein (47). How such membrane proteins transduce extracellular signals is still a mystery but may involve associated tyrosine kinases (48). LPS action in macrophages includes priming for enhanced $\left[{ }^{3} \mathrm{H}\right] \mathrm{AA}$ release $(49-51)$ and activation of protein tyrosine phosphorylation (52). How LBP accelerates LPS priming is not known but apparently involves increasing the rate of post-CD14 events. How LPS almost immediately increases cellular uptake of $\mathrm{OZ}$ is also unknown but suggests a very different mechanism of action. Finally, how the priming effects of LPS on AA metabolism are reversed (see Figs. 1 and 2 ) is unknown but reversal is apparently distinct from the phosphorylation event(s) that cause the gel shift and increased cell-free activity of $\mathrm{CPLA}_{2}$. With tumor necrosis factor as the priming agent (53), the transient nature of priming of PMN AA metabolism is also observed with effects on CPLA A $_{2}$ phosphorylation (gel shift) similar to LPS-priming (unpublished observations) suggesting that reversible priming is an inherent feature of complex mechanisms regulating AA metabolism $\left(\mathrm{CPLA}_{2}\right)$ activity in PMN.

\section{Acknowledgments}

We wish to thank Sheila Heitner (New York University) for her excellent technical assistance and Dr. Lih-Ling Lin (Genetics Institute) for her invaluable input into this work.

\section{References}

1. Young, I. S. 1990. Gram-negative sepsis. In Principles and Practice of Infectious Disease. R. G. Mandell, Jr., G. S. Douglas, and J. E. Bennet, editors. Churchill Livingstone Inc., New York. 611-635.

2. Tobias, P. S., K. Soldau, and R. J. Ulevitch. 1986. Isolation of a lipopolysaccharide-binding acute phase reactant from rabbit serum. J. Exp. Med. 164:777793.

3. Wright, S. D., R. A. Ramos, P. S. Tobias, R. J. Ulevitch, and J. C. Mathison. 1990. CD14, a receptor for complexes of lipopolysaccharide (LPS) and LPS binding protein. Science (Wash. DC). 249:1431-1433.

4. Doerfler, M. E., R. L. Danner, J. H. Shelhamer, and J. E. Parrillo. 1989. Bacterial Lipopolysaccharides prime human neutrophils for enhanced production of leukotriene $B_{4}$. J. Clin. Invest. 83:970-977.

5. Ford-Hutchinson, A. W., M. A. Bray, M. V. Doig, M. E. Shipley, and J. H. Smith. 1980. Leukotriene B, a potent chemokinetic and aggregating substance released from polymorphonuclear leukocytes. Nature (Lond.). 286:264-265.

6. Wedmore, C. V., and T. J. Williams. 1981. Control of vascular permeability by polymorphonuclear leukocytes in inflammation. Nature (Lond.). 289:646-650.

7. Fujimori, Y., M. Murakami, D. Y. Kim, S. Hara, K. Takayama, I. Kudo, and K. Inoue. 1992. Immunochemical detection of arachidonoyl-preferential phospholipase $A_{2}$. Biochem. J. 111:54-60.

8. Xing, M., and R. Mattera. 1992. Phosphorylation-dependent regulation of phospholipase $\mathrm{A}_{2}$ by $\mathrm{G}$-proteins and $\mathrm{Ca}^{2+}$ in $\mathrm{HL} 60$ granulocytes. J. Biol. Chem. 267:25966-25975

9. Clark, J. D., N. Milona, and J. L. Knopf. 1990. Purification of a 110-kilodalton cytosolic phospholipase $\mathrm{A}_{2}$ from the human monocytic cell line U937. Proc. Natl. Acad. Sci. USA. 87:7708-7712.

10. Kramer, R. M., E. F. Roberts, J. Manetta, and J. E. Putnam. 1991. The $\mathrm{Ca}^{2+}$-sensitive cytosolic phospholipase $\mathrm{A}_{2}$ is a $100-\mathrm{kDa}$ protein in human monoblast U937 cells. J. Biol. Chem. 266:5268-5272.

11. Diez, E., and S. Mong. 1990. Purification of a phospholipase A from human monocytic leukemic U937 cells. J. Biol. Chem. 265:14654-14661.

12. Victor, M., J. Weiss, M. S. Klempner, and P. Elsbach. 1981. Phospholipase $\mathrm{A}_{2}$ activity in the plasma membrane of human polymorphonuclear leukocytes. FEBS (Fed. Eur. Biochem. Soc.) Lett. 136:298-300.

13. Wright, G. W., C. E. Ooi, J. Weiss, and P. Elsbach. 1990. Purification of a cellular (granulocyte) and an extracellular (serum) phospholipase $A_{2}$ that participates in the destruction of Escherichia coli in a rabbit inflammatory exudate. $J$. Biol. Chem. 265:6675-6681.

14. Balsinde, J., E. Diez, and F. Mollinedo. 1991. Arachidonic acid release from diacylglycerol in human neutrophils. J. Biol. Chem. 266:15638-15643.

15. Wright, S. D., R. A. Ramos, A. Hermanowsky-Vosatka, P. Rockwell, and P. A. Detmers. 1991. Activation of the adhesive capacity of CR3 on neutrophils by endotoxin: dependence on lipopolysaccharide binding protein and CD14. J. Exp. Med. 173:1281-1286.

16. Lynn, W. A., C. R. H. Raetz, N. Qureshi, and D. T. Golenbock. 1991. Lipopolysaccharide-induced stimulation of CD1 lb/CD18 expression on neutrophils. Evidence of specific receptor-based response and inhibition by lipid Abased antagonists. J. Immunol. 147:3072-3079.

17. Klein, J. B., V. Payne, T. M. Schepers, and K. R. McLeish. 1990. Bacterial lipopolysaccharide enhances polymorphonuclear leukocyte function independent of changes in intracellular calcium. Inflammation. 14:599-611.

18. Palma, C., A. Cassone, D. Serbousek, C. A. Pearson, and J. Y. Djeu. 1992. Lactoferrin release and interleukin-1, interleukin-6, and tumor necrosis factor production by human polymorphonuclear cells stimulated by various lipopolysaccharides: relationship to growth inhibition of Candida albicans. Infect. Immun. 60:4604-4611.

19. Shak, S. 1987. Leukotriene $B_{4}$ catabolism: quantitation of leukotriene $B_{4}$ and its omega-oxidation products by reversed-phase high-performance liquid chromatography. Methods Enzymol. 141:355-371.

20. Clark, J. D., L. L. Lin, R. W. Kriz, C. S. Ramesha, L. A. Sultzman, A. Y. Lin, N. Milona, and J. L. Knopf. 1991. A novel arachidonic acid-selective cytosolic PLA $\mathrm{PL}_{2}$ contains a $\mathrm{Ca}^{2+}$-dependent translocation domain with homology to PKC and GAP. Cell. 65:1043-1051.

21. Guthrie, L. A., L. C. McPhail, P. M. Henson, and R. B. Johnston, Jr. 1984. Priming of neutrophils for enhanced release of oxygen metabolites by bacterial lipopolysaccharide. J. Exp. Med. 160:1656-1671. 
22. Bligh, E. G., and W. J. Dyer. 1959. A rapid method of total lipid extraction and purification. Can. J. Biochem. Physiol. 37:911-919.

23. Kaluzny, M. A., L. A. Duncan, M. V. Merritt, and D. E. Epps. 1985. Rapid separation of lipid classes in high yield and purity using bonded phase columns. J. Lipid Res. 26:135-140.

24. Rouser, G., S. Fleischer, and A. Yamamoto. 1970. Two dimensional thin layer chromatographic separation of polar lipids and determination of phospholipids by phosphorous analysis of spots. Lipids. 5:494-496.

25. Elsbach, P., P. Pettis, S. Beckerdite, and R. Franson. 1973. Effects of phagocytosis by rabbit granulocytes on macromolecular synthesis and degradation in different species of bacteria. J. Bacteriol. 115:490-497.

26. Ulevitch R. J., Y. Watanabe, M. Sano, M. D. Lister, R. A. Deems, and E. A. Dennis. 1988. Solubilization, purification, and characterization of a membrane-bound phospholipase $A_{2}$ from the $P 388 D_{1}$ macrophage-like cell line. $J$. Biol. Chem. 263:3079-3085.

27. Lin, L. L., A. Y. Lin, and J. Knopf. 1992. Cytosolic phospholipase $A_{2}$ is coupled to hormonally regulated release of arachidonic acid. Proc. Natl. Acad. Sci. USA. 89:6147-6151.

28. Philips, M. R., S. B. Abramson, S. L. Kolasinski, K. A. Haines, G. Weissman, and M. G. Rosenfeld. 1991. Low molecular weight GTP-binding proteins in human neutrophil granule membranes. J. Biol. Chem. 266:1289-1298.

29. Vosbeck, K., P. Tobias, H. Mueller, R. A. Allen, K. E. Arfors, R. J. Ulevitch, and L. A. Sklar. 1990. Priming of polymorphonuclear granulocytes by lipopolysaccharides and it's complexes with lipopolysaccharide binding protein and high density lipoprotein. J. Leukocyte Biol. 47:97-104.

30. Alonso, F., P. M. Henson, and C. C. Leslie. 1986. A cytosolic phospholipase in human neutrophils that hydrolyzes arachidonoyl-containing phosphatidylcholine. Biochim. Biophys. Acta. 878:273-280.

31. Franson, R., P. Patriarca, and P. Elsbach. 1974. Phospholipid metabolism by phagocytic cells. Phospholipases $A_{2}$ associated with rabbit polymorphonuclear leukocyte granules. J. Lipid Res. 15:380-388.

32. Forst, S., J. Weiss, P. Elsbach, J. M. Maraganore, I. Reardon, and R. L. Heinrikson. 1986. Structural and functional properties of a phospholipase $A_{2}$ purified from an inflammatory exudate. Biochemistry. 25:8381-8385.

33. Wright, G. C., J. Weiss, K. S. Kim, H. Verheij, and P. Elsbach. 1990. Bacterial phospholipid hydrolysis enhances the destruction of Escherichia coli ingested by rabbit neutrophils. J. Clin. Invest. 85:1925-1935.

34. Raaflaub, J. 1960. Applications of metal buffers and metal indicators in biochemistry. Methods Biochem. Anal. 3:301-325.

35. Lin, L. L., M. Wartmann, A. Y. Lin, J. Knopf, A. Seth, and R. J. Davis. 1993. cPLA $_{2}$ is phosphorylated and activated by MAP kinase. Cell. 72:269-278.

36. Chilton, F. H., and T. R. Connell. 1988. 1-Ether-linked phosphoglycerides. J. Biol. Chem. 263:5260-5265.

37. Chilton, F. H. 1989. Potential phospholipid source(s) of arachidonate used for the synthesis of leukotrienes by the human neutrophil. Biochem. $J$. 258:327-333.

38. Clancy, R. M., C. A. Dahinden, and T. E. Hugli. 1983. Arachidonate metabolism by human polymorphonuclear leukocytes stimulated by $\mathrm{N}$-formylMet-Leu-Phe or complement component C5a is independent of phospholipase activation. Proc. Natl. Acad. Sci. USA. 80:7200-7204.
39. Balsinde, J., E. Diez, A. Schuller, and F. Mollinedo. 1988. Phospholipase $A_{2}$ activity in resting and activated human neutrophils. J. Biol. Chem. 263:19291936.

40. Forehand, J. R., M. J. Pabst, W. A. Phillips, and R. B. Johnston. 1989. Lipopolysaccharide priming of human neutrophils for an enhanced respiratory burst: role of intracellular free calcium. J. Clin. Invest. 83:74-83.

41. Korchak, H. M., L. B. Vosshal, G. Zagon, P. Lubich, A. M. Rich, and G. Weissman. 1988. Activation of the neutrophil by calcium-mobilizing ligands. $J$. Biol. Chem. 263:11090-11097.

42. Naccache, P. H., T. F. P. Molski, P. Borgeat, J. R. White, and R. I. Sha'afi. 1985. Phorbol esters inhibit the f-Met-Leu-Phe and leukotriene $B_{4}$-stimulated calcium mobilization and enzyme secretion in rabbit neutrophils. J. Biol. Chem. 260:2125-2131.

43. Castagna, M., Y. Takai, K. Kaibuchi, K. Sano, U. Kikkawa, and Y. Nishizuka. 1982. Direct activation of calcium-activated, phospholipid-dependent protein kinase by tumor promoting phorbol esters. J. Biol. Chem. 257:7847-7851.

44. Sha'af, R. I., J. R. White, T. F. P. Molski, J. Shefcyk, M. Volpi, P. H. Naccache, and M. B. Feinstein. 1983. Phorbol-12-myristate-13-acetate activates rabbit neutrophils without an apparent rise in the level of intracellular free calcium. Biochem. Biophys. Res. Commun. 114:638-645.

45. Nemenoff, R. A., S. Winitz, N. X. Qian, V. Van Putten, G. L. Johnson, and L. Heasley. 1933. Phosphorylation and activation of a high molecular weight form of phospholipase $A_{2}$ by $p 42$ microtubule-associated protein 2 kinase and protein kinase C. J. Biol. Chem. 268:1960-1964.

46. Lund-Johansen, F., J. Olweus, A. Aarli, and R. Bjerknes. 1990. Signal transduction in human monocytes and granulocytes through the PI-linked antigen CD14. FEBS (Fed. Eur. Biochem. Soc.) Lett. 273:55-58.

47. Haziot, A., S. Chen, E. Ferrero, M. G. Low, R. Silber, and S. M. Goyert. 1988. The monocyte differentiation antigen CD14, is anchored to the cell membrane by a phosphatidylinositol linkage. J. Immunol. 141:547-552.

48. Stefanova, I., V. Horejsi, I. J. Ansotegui, W. Knapp, and H. Stockinger. 1991. GPI-anchored cell-surface molecules complexed to protein tyrosine-kinases. Science (Wash. DC). 254:1016-1019.

49. Aderem, A. A., D. S. Cohen, S. D. Wright, and Z. A. Cohn. 1986. Bacterial lipopolysaccharides prime macrophages for enhanced release of arachidonic acid metabolites. J. Exp. Med. 164:165-179.

50. Aderem, A. A., and Z. A. Cohn. 1988. Calcium ionophore synergizes with bacterial lipopolysaccharides in activating macrophage arachidonic acid metabolism. J. Exp. Med. 167:623-631.

51. Glaser, K. B., R. Asmis, and E. A. Dennis. 1990. Bacterial lipopolysaccharide priming of $\mathrm{P}_{388} \mathrm{D}_{1}$ macrophage-like cells for enhanced arachidonic acid metabolism. J. Biol. Chem. 265:8658-8664.

52. Weinstein, S. L., M. R. Gold, and A. L. DeFranco. 1991. Bacterial lipopolysaccharide stimulates protein tyrosine phosphorylation in macrophages. Proc. Natl. Acad. Sci. USA. 88:4148-4152.

53. Bauldry, S. A., C. E. McCall, S. L. Cousart, and D. A. Bass. 1991. Tumor necrosis factor- $\alpha$ priming of phospholipase $A_{2}$ activation in human neutrophils. An alternative mechanism of priming. J. Immunol. 146:1277-1285.

54. Laemmli, U. K. 1970. Cleavage of structural proteins during the assembly of the head of bacteriophage T4. Nature (Lond.). 227:680-685. 